\title{
INTERNATIONAL COOPERATION IN ARCTIC RESEARCH $^{1}$
}

\section{By A. L. WASHBURN}

$\mathrm{P}$ ROBABLY in few regions of the world are the opportunities for international scientific cooperation greater than in the Far North. From west to east, the United States (Alaska), Canada, Newfoundland (Labrador), Iceland, Denmark (Greenland), Norway, Sweden, Finland, and the Soviet Union are all vitally concerned in Arctic and Subarctic problems. And many other countries have contributed significant chapters in the ever-expanding book of knowledge entitled "The North".

Scientific problems are similar regardless of international boundaries, and the number of problems in the Arctic and Subarctic that can be best solved by international cooperation is legion. In fact many of them can be solved only by international cooperation. The desirability of such cooperation and of a circumpolar background is stressed by Professor V. C. Wynne-Edwards": "Parallel investigations along many lines are being made in Alaska, Scandinavia and the U.S.S.R. The importance, from the purely scientific as well as the practical and economic standpoint, of acquainting the investigators of this country at first hand with similar problems and conditions in other northern lands cannot be too strongly stressed. Understanding and insight are born of experience; and the need for a circumpolar background must be evident to many besides myself."

Considerable cooperative work has been done in the fields of meteorology and climatology, especially through the rapid exchange of observations for forecasting purposes. Although most of this cooperative effort has been confined to non-Arctic investigations, the need for focusing more attention to Arctic weather is becoming apparent. As Dr. F. W. Reichelderfer (Ibid, p. I I) points out, more information is needed on "Connections and interactions between the semi-permanent centers such as: The Aleutian low, Icelandic low, Siberian high, Greenland high or low, North American high, Azores-Bermuda high, Polar high, Asiatic monsoons, etc." The very terms used by Dr. Reichelderfer point to the international character of the problem. Its importance is seen in the fact that much of the weather affecting more southerly regions originates in the Far North. The greatest ice cap in the Northern Hemisphere lies on Greenland and although its exact effect on weather elsewhere is not well-known it is certainly international in character.

Like weather, oceanography offers problems to all the countries fronting the Arctic Sea. Greenland, Iceland, Norway, Finland, and the Soviet Union

1Summarized from a statement in Biologia, Vol. I, No. 6, Autumn 1947, pp. 23-4, by permission.

${ }^{2}$ The Arctic Institute of North America (1946): A program of desirable scientific investigations in Arctic North America, p. 30-31. 
are all influenced by the Gulf Stream, to a greater or less degree, to cite just one of the common denominators which requires cooperative effort for its thorough study. The course of the Gulf Stream is not a rigidly fixed thing but varies slightly. It is most important to keep a close watch of these variations, for the Gulf Stream can affect the everyday life of man in the North in a number of ways; for instance, by influencing climate, controlling the sites of commercial fisheries, and in facilitating ice-free navigation in high latitudes as at Murmansk. In many places oceanographical investigations, especially those dealing with currents, should be carried out by simultaneous observations by countries fronting a common body of water. Less than sixty miles separate the shores of Siberia from Alaska. Here in Bering Strait alone there exist an abundance of oceanographical problems such as tides, currents, sea ice, and others whose cooperative study would materially benefit science as a whole as well as the two countries primarily involved.

Some phases of geology in the Arctic and Subarctic lend themselves extremely well to an international approach. The Pleistocene ice sheets of the Northern Hemisphere originated in the North, but it is not certain that they originated simultaneously in Europe, Asia, and North America, or that they underwent the same stages of growth and decay. The history of the Ice Age in Canada's Arctic Islands, in Greenland, Spitsbergen, Novaya Zemlya, Severnaya Zemlya, and other island groups in the Arctic Sea is even more of a mystery. Not only geology, but also climatology, botany, zoology, and numerous other subjects that know no national boundaries would be advanced by detailed information of what took place in the Arctic and Subarctic during the Ice Age.

Problems of natural history offer a very promising opportunity for international cooperation in Arctic research. Arctic fishes are an example. According to Dr. Leonard P. Schultz (Ibid, p. 45) "Adequate collections of fishes, including freshwater fishes, marine-shore, pelagic, deep-sea, and bottom fishes, have never been made, except possibly around Iceland and northern Europe. This leaves all of the polar seas, northern Asia, and northern North America and Greenland, regions yet to be explored ichthyologically."

Newfoundland seals move to West Greenland and to the Canadian Eastern Arctic in the spring. Seals breeding in the Jan Mayen area may go to West Greenland in the summer. Thus some seals, like some migratory birds, are international travelers. Many seals breed off Newfoundland and sealing here is commercially profitable and a national industry. On the other hand, Greenlanders and Canadian Eskimos depend to a large extent on seals for their daily food and clothing, and some of these seals come from New- 
foundland. Thus these international travelers become an international conservation problem.

That there are a number of illustrations of international action on conservation problems is seen in treaties related to fisheries, seals, whales, and migratory birds. An example is the agreement between the Soviet Union, United States, Canada and Japan which has prevented the extermination of the fur seal. Since cooperation can be obtained on problems where national economic interests are an important factor, it should be still easier for scientists of different countries to work together on problems, such as the glacial and post-glacial history of faunas and floras throughout the North, where national economic and political interests are minimal.

International cooperation is absolutely essential to the solution of problems dealing with the broad history of faunas and floras. The freshwater fauna of the Mackenzie Valley, which is a mixture involving Siberian elements, is an example. Dr. Austin H. Clark (Ibid, p. 34) points out that "... arctic North America and arctic Asia are but different sections of the same great faunal and floral province with many animals and plants in common. . . ." The number of problems demanding eventual cooperation in this field alone are therefore countless. Dr. Raymond M. Gilmore (Ibid, p. 35) writes, "Much of our American arctic mammalian fauna needs to be taxonomically revised, especially with Siberian specimens for comparison." The former existence of a land bridge across the present site of Bering Strait, plays a large role here. Dr. Gilmore continues ". . . the whole Beringian region is a faunistic endemic area, and moreover, it is the bridge-area between the Western and Eastern Hemispheres; all the great and near-great of the intercontinental emigrators and immigrators, and the small-fry, slept there."

International cooperation is also essential in solving the problems surrounding primitive man who spread from Siberia, across Alaska to northern Canada and Greenland. More archeological investigations and linguistic studies must be undertaken in all these places. For instance, following. Dr. Henry B. Collins, Jr., (Ibid, p. 5o, 52) "It seems safe to say that the important problems of the physical and cultural relationships of the Aleuts to neighboring peoples in Alaska and Siberia cannot be solved on the basis of the materials now available." He believes, "Systematic excavation in northeast Siberia is the greatest desideratum in Eskimo archaeology. . . ."

Not only the past history of man in the Arctic requires the cooperation of all northern countries for its accurate delineation, but also the present day to day activities of northern dwellers requires this working together. The pooling of experience gained under similar environmental conditions is of mutual benefit. Take for instance northern agriculture which requires 
hardy seeds. Different varieties are known from investigations in a number of northern countries, and the international exchange of agricultural information and seeds cannot help but be beneficial to all parties concerned.

International cooperation is called for in all the above fields of Arctic research. There are many others that could have been added. Although treated as different fields of scientific work, they are really so interdependent that they become merely different phases of one international regional problem-the Arctic. The day to day exchange of published scientific papers among specialists, informal correspondence, joint expeditions, and the close cooperation of scientific societies and research institutes are all ways of facilitating international cooperation in solving the many problems that exist in the Arctic and Subarctic.

\section{ASSOCIATES OF THE ARCTIC INSTITUTE}

During the formative years of the Arctic Institute many friends expressed the hope that a means of close association with its objectives might be made possible. In response to this expression the Institute has developed a membership program for Associates of the Arctic Institute. Associates will receive the journal of the Institute biannually and other reports from time to time. The chief qualification for Associate Membership is interest in Arctic work, and the Board of Governors will welcome the widest possible participation. Dues are \$3.oo annually and may be paid in United States or Canadian funds and forwarded to either the New York or Montreal offices of the Institute.

In addition, a class of Fellows of the Arctic Institute is being planned for the near future, the Fellows to be selected from Associates of the Arctic Institute who have done distinguished work in relation to the Polar Regions. It is contemplated that Fellows will take a leading part in Institute affairs and will have the privilege of electing a proportion of the Board of Governors. 